\title{
PENGARUH FAKTOR CURAH HUJAN DAN ALIRAN PERMUKAAN UNTUK PROGNOSA DEBIT DAN INDEK BANJIR DALAM MENGURANGI RESIKO BENCANA BAHAYA BANJIR PADA DAERAH DATARAN BANJIR ALIRAN SUNGAI
}

\author{
Nofrizal \\ Teknik Sipil Institut Teknologi Padang Padang \\ nofri-sk@yahoo.com \\ DOI: http://dx.doi.org/10.31869/rtj.v2i2.1383
}

\begin{abstract}
Abstrak: Batang Kuranji merupakan salah satu sungai yang melintasi Kota padang dan bermuara di wilayah bagian utara kota yang merupakan bagian dari wilayah Kota Padang. Topografi di bagian hulu merupakan daerah perbukitan dengan lembah sungai yang sempit dan kelandaian yang relatif curam, sedang dibagian tengah merupakan dataran rendah dengan kemiringan dasar sungai landai. Bagian hilir sungai Bt Kuranji bermuara di Pantai Padang yang merupakan Daerah Perumahan dan fasilitas social lainnya. Permasalahan dominan yang dihadapi kawasan ini adalah genangan air yang terjadi setiap musim hujan yang menggenangi sebagian besar kawasan di sepanjang alur sungai utama bagian hilir yang merupakan salah satu anak sungai. Genangan banjir yang rutin terjadi diantaranya sekitar kecamatan nangghalo,siteba sekitarnya. Dalam penelitian ini untuk mencari mencari besaran indeks banjir dalam upaya mitigasi parameter yang beresiko terhadap bahaya banjir di wilayah tersebut selalu siap dan waspada dalam segala rencana maupun pelaksanaan aktifitas kegiatan. Metodologi yang dipakai dalam penelitian ini pendekatan metoda diskriptif, sehingga didapatkan simulasi - simulasi bahaya banjir pada setiap daerah dataran banjirnya sepanjang alur sungai batang kuranji ini.Dari hasil analisis data didapat debit puncak pada periode ulang 100 tahun sebesar 1079.4 $\mathrm{m} 3 / \mathrm{dt}$,dengan tinggi genangan $0.20 \mathrm{~m}$ sampai $3.66 \mathrm{~m}$ pada daerah sub Das kuaranji 2 pada daerah dataran banjir,dengan luas genangan 28 hektar
\end{abstract}

\section{Key Wood :Banjir,DAS Kuranji,Flood Pland,Mitigasi Banjir}

\section{LATAR BELAKANG}

Batang Kuranji merupakan salah satu sungai yang melintasi Kota padang dan bermuara di wilayah bagian utara kota yang merupakan bagian dari wilayah Kota Padangi. Kondisi geografis Kota Padang merupakan daerah dataran dengan muka air tanah relatif tinggi. Sungai Batang Kuranji mengalir melalui dua wilayah administrasi yaitu Kecamatan Pauh sekitarnya (bagian hulu dan hilir) dan Kecamatan Nanggalo (bagian tengah),dan muaranya sebagian kecamatan padangBarat. Topografi di bagian hulu merupakan daerah perbukitan dengan lembah sungai yang sempit dan kelandaian yang relatif curam, sedang dibagian tengah merupakan dataran rendah dengan kemiringan dasar sungai landai. Bagian hilir sungai Bt Kuranji bermuara di Pantai Padang yang merupakan Daerah Perumahan dan fasilitas social lainnya. Beberapa peneliti terdahulu telah membuktikan, dengan adanya perubahan penggunaan tata guna lahan dari lahan hijau menjadi lahan pemukiman pada daerah tangkapan DAS akan menyebabkan kenaikan debit aliran permukaan dari tahun 1995 sampai tahun 2002 rata-rata sebesar 6,39\%, (Pranoto SA,dkk,2001). Akibat perubahan tata guna lahan dari lahan hijau ke lahan pemukiman,tanpa adanya kompensasi pengganti bangunan resapan dihulu daerah hulu sungai maupun dalam daerah DAS akan mengakibatkan kenaikan debit puncak sampai 25 kali karna intensitas hujan yang turun cendrung menjadi aliran runoff karna daearh resapan telah berobah fungsi,(Adipandang.Y,2011). Ditinjau dari kondisi sungainya, alur sungai Batang Kuranji yang dangkal dan sempit disebabkan karena akumulasi sedimen pada palung sungai serta sudah ada perkuatan tebing sungai yang dibangun oleh masyarakat yang bermukim di sepanjang sungai untuk pengembangan pemukiman. Permasalahan dominan yang dihadapi kawasan ini adalah genangan air yang terjadi setiap musim hujan yang menggenangi sebagian besar kawasan di sepanjang alur sungai utama bagian hilir yang merupakan salah satu anak sungai. Genangan banjir yang 
rutin terjadi diantaranya sekitar kecamatan nangghalo,siteba sekitarnya,. Penanganan dan studi tentang banjir Kota Padang sudah cukup banyak dibuat oleh instansi terkait dan sebagian telah pula diimplementasikan. Salah satunya dapat dilihat dari pembangunan alur sungai dan Bangunan pengendalian sedimen sungai batang kuranji ini. yang sebagian telah dinormalisasi dan dilengkapi dengan bangunanbangunan pengendalian sungai dan sedimen,terkait peningkatan debit pengaliran sungai. Namun demikian, permasalahan banjir tidak serta merta dapat diselesaikan (Anonim, 2009). Penyebab terjadinya banjir akibat aliran relatif tinggi yang mengakibatkan meluap (overtopping) dari tanggul sungai. Ketika terjadi luapan, air mengalir pada dataran banjir (floodplain Area). Menurut Suryadi (2006), fluktuasi muka air sungai dipengaruhi oleh perubahan debit yang masuk (hidrograph inflow) ke sungai,dimana hidrograf inflow yang paling berpengaruh terhadap banjir adalah debit puncak (Qp).Menurut Sutan (2004), di negara-negara maju prediksi akan terjadinya banjir sudah dilakukan dengan adanya early warning system dan biasanya dengan cara memperkirakan kejadian hujan yang terjadi saat itu. Dengan maksud untuk meminimalkan dampak bahaya banjir pada kawasan Kota penyangga Metropolitan Palapa ( Padang Lubuk Alung Dan Pariaman ), maka diadakan penelitian ini untuk mendapatkan suatu indikator yang dapat memberikan gambaran suatu wilayah terhadap kemungkinan terjadinya banjir, berapa luas genangan, tinggi genangan dan lama waktu genang secara tepat dan cepat. Dengan diketahuinya indeks banjir tersebut, hal yang beresiko terhadap bahaya banjir di wilayah tersebut selalu siap dan waspada dalam segala rencana maupun pelaksanaan aktifitas kegatan

\section{LITERATUR REVIEW Daerah Aliran Sungai}

Daerah Aliran Sungai (DAS) dianggap sebagai wilayah dari suatu titik tertentu pada suatu sungai dan dipisahkan dari DAS-DAS di sebelahnya oleh suatu pembagi (divide), atau pungung bukit/gunung yang dapat ditelusuri pada peta topografi. Semua air permukaan yang berasal dari daerah yang dikelilingi oleh pembagi tersebut dialirkan melalui titik terendah pembagi, yaitu tepat yang dilalui oleh sungai utama pada DAS yang bersangkutan. (Linsley, R.K. and Franzini. J.B.,1985). DAS juga dikatakan sebagai suatu area daratan yang mengalirkan air ke suatu aliran pada lokasi tertentu. Batas DAS adalah sebuah garis yang membagi lahan yang mengalirkan aliran dari lahan tersebut menuju ke arah sungai. Batas sistem digambar mengelilingi DAS tersebut arah vertikal ke atas maupun ke bawah (Chow V. T., dkk., 1964) seperti gambar berikut :

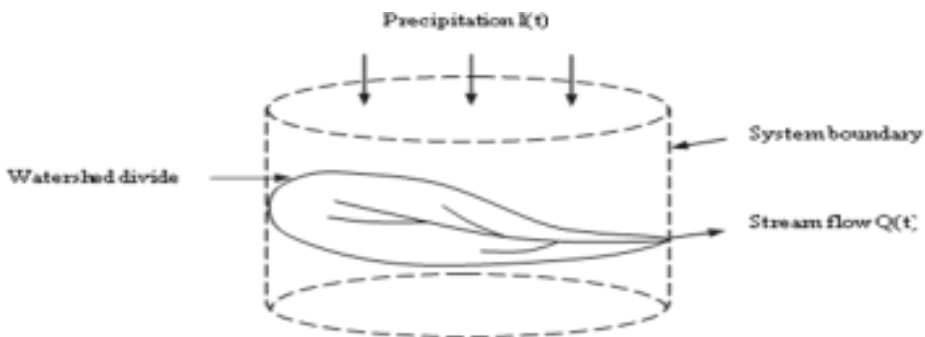

\section{Gambar.1 DAS Sebagai Sistem Hidrologi Banjir dan Penyebabnya}

Penyebab banjir dapat dibagi dalam dua kelompok yaitu banjir akibat alami dan banjir akibat aktivitas manusia. Banjir akibat alami dipengaruhi oleh curah hujan, fisiografi, erosi dan sedimentasi, kapasitas sungai, kapasitas drainase dan pengaruh air pasang. Sedangkan banjir akibat aktivitas manusia disebabkan karena ulah manusia yang menyebabkan perubahan-perubahan lingkungan seperti perubahan kondisi Daerah Aliran Sungai (DAS), kawasan pemukiman di sekitar bantaran, rusaknya drainase lahan, kerusakan bangunan pengendali banjir, rusaknya hutan (vegetasi alami), dan perencanaan sistem pengendali banjir yang tidak tepat dan perubahan tata guna lahan (Sebastian, 2008). Flood plain adalah daerah lahan kering dalam keadaan normal yang berada di sekitar sungai, danau, teluk atau pantai yang tergenang pada saat terjadi banjir. Flood plain dapat berupa lembah yang lebar sepanjang sungai atau lembah yang datar seperti yang dapat dilihat pada gambar di bawah ini. 


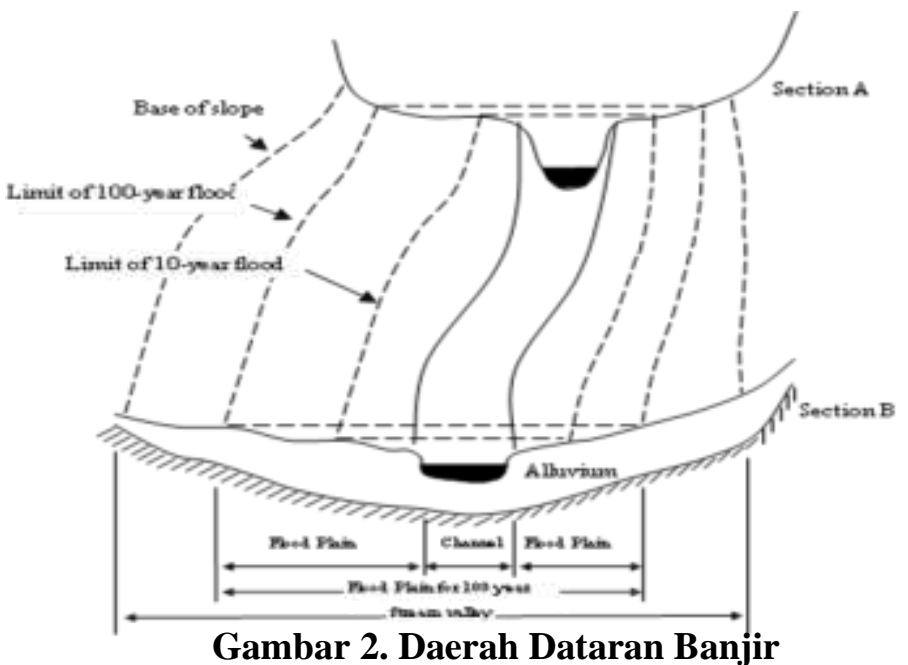

Debit inflow dalam penelitian ini adalah debit yang masuk ke sungai utama hasil simulasi rainfall runoff dari sebuah DAS. Karena indeks yang didesain adalah indeks debit inflow yang me- rupakan bagian dari indeks banjir, maka tidak semua debit pun- cak dapat digunakan dalam menentukan nilai indeks debit. Hanya debit-debit puncak yang dapat menimbulkan banjir saja yang berpengaruh dalam menentukan indeks debit. Indeks Debit Inflow dirumuskan sebagai perbandingan an- tara debit banjir yang terjadi dikurangi debit minimum dengan tenggang debit antara maksimum dengan minimum seperti formula berikut:

\section{Penilaian Terhadap Resiko (Hazard Assesment)}

Menurut Dimitriou (2003), dua parameter penting dalam analisis resiko banjir pada penelitian ini yaitu L dan R. L dipre- sentasikan sebagai beban (loading) dan $\mathrm{R}$ sebagai tahanan (re- sistance). Dalam penelitian ini tahanan, $\mathrm{R}$ adalah kapasitas pe- nampang sungai (bankfull capacity) dan L adalah debit yang me- lewati penampang sungai tersebut. Penampang yang ditinjau ada- lah penampang-penampang sungai yang dapat terluapi pada saat debit puncak, yaitu penampang yang berada di sekitar lokasi ban- jir. Probabilitas keamanan terhadap banjir adalah Pr dan proba- bilitas terhadap resiko banjir adalah Pf yang didefinisikan se- bagai:

$\operatorname{Pr}=\mathrm{P}(\mathrm{R} \geq \mathrm{L})=\mathrm{P}(\mathrm{S} \geq 1)$
Dimana $S=R / L$ adalah faktor keamanan. Dalam penelitian ini kapasitas penampang adalah tetap, jadi nilai $\mathrm{R}$ adalah konstan, sedangkan debit merupakan variable random. Apabila L mempu- nyai distribusi normal, maka persamaan evaluasi terhadap probabilitas tahanan dengan $\mathrm{R}$ yang konstan adalah : Analisis indeks bahaya banjir dilakukan berdasarkan peta genangan banjir hasil pemodelan. Peta genangan banjir dimodelkan dengan model matematis 1-D takunak DUFLOW (Kusuma et. al, 2007). Model 1-D ini dipakai dengan asumsi bahwa aliran sungai tetap satu arah walaupun banjir memenuhi saluran dan bantaran. Bantaran yang dimodelkan tidak lebar sehingga aliran arah melintang saluran diasumsikan dapat diabaikan. Air yang melimpas ke bantaran akan dilihat dari lebihnya hidrograf aliran terhadap kapasitas saluran, sehingga volume yang berlebih dianggap sebagai sumber genangan. Peta resiko banjir secara kualitatif disusun berdasarkan peta indeks bahaya banjir, indeks kerentanan dan indeks kapasitas yang dihubungkan sebagai berikut (Kusuma et. al, 2009):

Resiko $=[$ Indeks Bahaya Banjir $\mathbf{x}$ Indeks Kerentanan ] / Indeks Kapasitas

Resiko banjir secara kualitatif, dibagi atas empat sifat resiko yang terjadi yaitu rendah, moderat, tinggi dan sangat tinggi. Peta resiko disusun berdasarkan dua skenario, yaitu eksisting dan intervensi. Kedua skenario ini merupakan efek samping dari analisis indeks kapasitas berdasarkan keadaan sebenarnya.

$\mathrm{Pf}=\mathrm{Pr}-1=\mathrm{P}(\mathrm{R}<\mathrm{L})=\mathrm{P}(\mathrm{S}<1$ 


\section{METODOIOGI}

Potensi banjir diperoleh dari analisis data curah hujan dengan berbagai kala ulang dalam bentuk hidrograf banjir dimodelkan dengan bantuan program perangkat lunak Mike Flood .Untuk mengetahui potensi lokasi dan tinggi luapan pada alur sungai. Analisis hidrologi dilakukan untuk menentukan syarat batas hulu dalam pemodelan yang dalam hal ini berupa hidrograf banjir. Dari data hujan harian yang diperoleh melalui BMKG, dilakukan perhitungan untuk memperoleh hujan rata-rata DAS dengan menggunakan metode polygon Thiessen.

Kemudian dilakukan analisis frekuensi untuk memperkirakan curah hujan rancangan dengan berbagai kala ulang, dimana sebelumnya dilakukan uji distribusi konsistensi data hujan untuk mengetahui penyimpangan data hujan. Mengingat di lokasi tinjauan tidak terdapat pencatatan debit, maka debit banjir dihitung dengan alih ragam dari pengolahan data frekuensi curah hujan menjadi debit dengan menggunakan metode hidrograf satuan sintetik Nakayasu. Analisis hidraulika dilakukan untuk mengetahui profil muka air di sungai baik dalam kondisi eksisting maupun pada kondisi dengan retarding basin. Analisis hidraulika dilakukan dengan mensimulasi aliran di sungai menggunakan model matematik dengan bantuan program Mike Flood, dimana sebelumnya dilakukan input data yaitu data debit banjir dengan kala ulang sebagai syarat batas hulu, data geometri dan bangunan serta data pasang surut sebagai syarat batas hilir. Setelah input data, dilakukan kalibrasi untuk menyesuaikan model dengan keadaan di lapangan, sehingga dapat mendekati kondisi yang sebenarnya (kondisi eksisting) tanpa kolam retensi. Model yang telah dikalibrasi kemudian di simulasi kembali dengan menambahkan kolam retensi, sehingga dapat diketahui perbedaan elevasi atau profil muka air sebelum (kondisi eksisting) dan setelah ada kolam retensi. Simulasi hidraulik 1D/2D dilakukan dengan menggunakan perangkat lunak Mike Flood. Simulasi 1D di Sungai dilakukan dengan menggunakan modul Mike 11. Simulasi 2D di area flood plain dilakukan dengan menggunakan perangkat lunak Mike 21. Modul Mike $11 \&$ Mike 21 diintegrasikan dengan modul Mike flood, sehingga simulasi 1D di sungai dan 2D di lahan terintegrasi. Dengan demikian kedua model running bersamaan dan interaksi pengaruh dari kedua model dapat update tiap time step pemodelan. Dengan mengkombinasikan kedua modul pemodelan maka user dapat menggunakan keistimewaan yang ada pada masing - masing aplikasi sehingga dihasilkan model yang terbaik dari kedua aplikasi tersebut. Untuk lebih jelasnya berikut ini skema tahapan pemodelan daerah genangan banjir dengan menggunakan program Mike Flood dijelaskan pada diagram Flow Chat berikut :

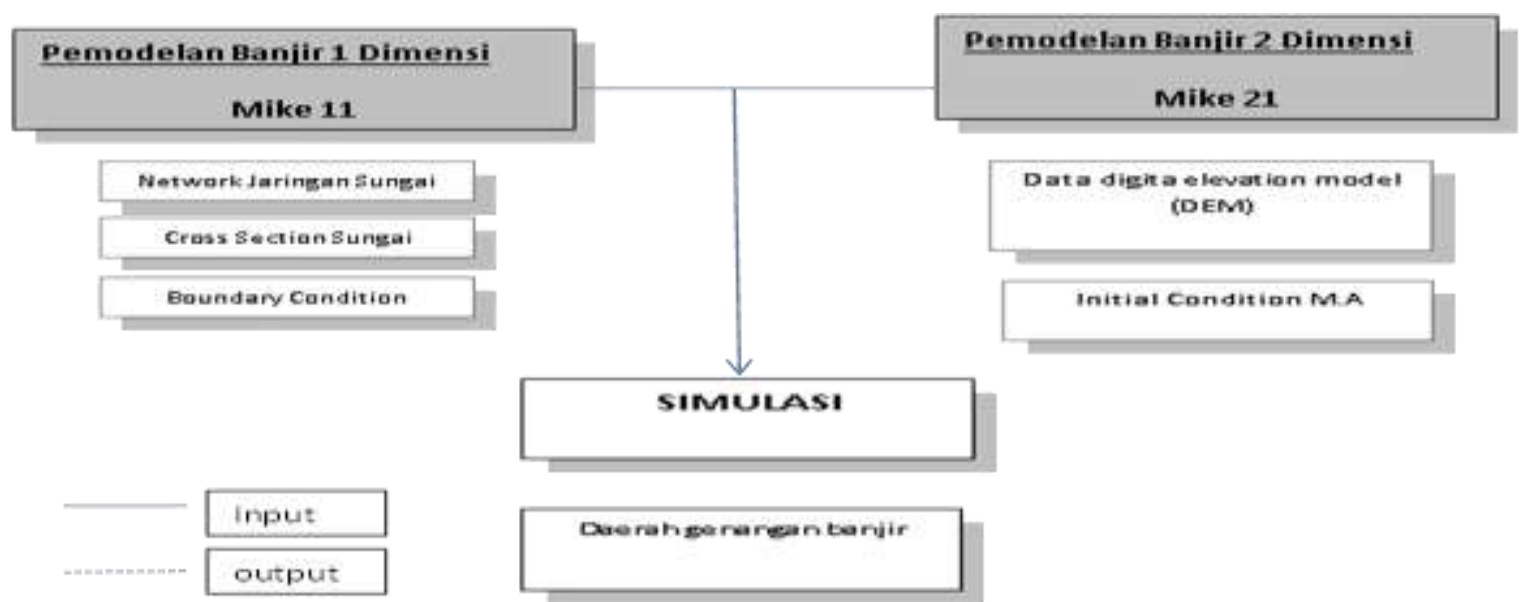

Gambar. 3 Flow Chat Penelitian

\section{HASIL DAN PEMBAHASAN Identifikasi Banjir}

Identifikasi banjir terbesar yang terjadi akibat luapan sungai Batang kuranji dan anak sungainya 20 tahun terakhir di Kota Padang, tercatat terjadi genangan banjir yang sebagian besar terjadi pada bagian hilir dari sungai yang merupakan daratan rendah dari Das, yang

$\begin{array}{lr}\text { Fakultas Teknik UMSB } & \text { ISSN 2599-2081 } \\ \text { EISSN 2599-2090 }\end{array}$


Vol. 2 No.2 Juni 2019

http://jurnal.umsb.ac.id/index.php/RANGTEKNIKJOURNAL

Rang Teknik Journal

termasuk kawasan Nanggalo,Siteba sekitarnya,dengan kedalaman banjir antara 0,3 sampai 1,5 meter. Menurut laporan dari BNPB

Sumatera Barat. (Anonim, 2014 ).sebagaimana ditunjukkan pada Gambar berikut.

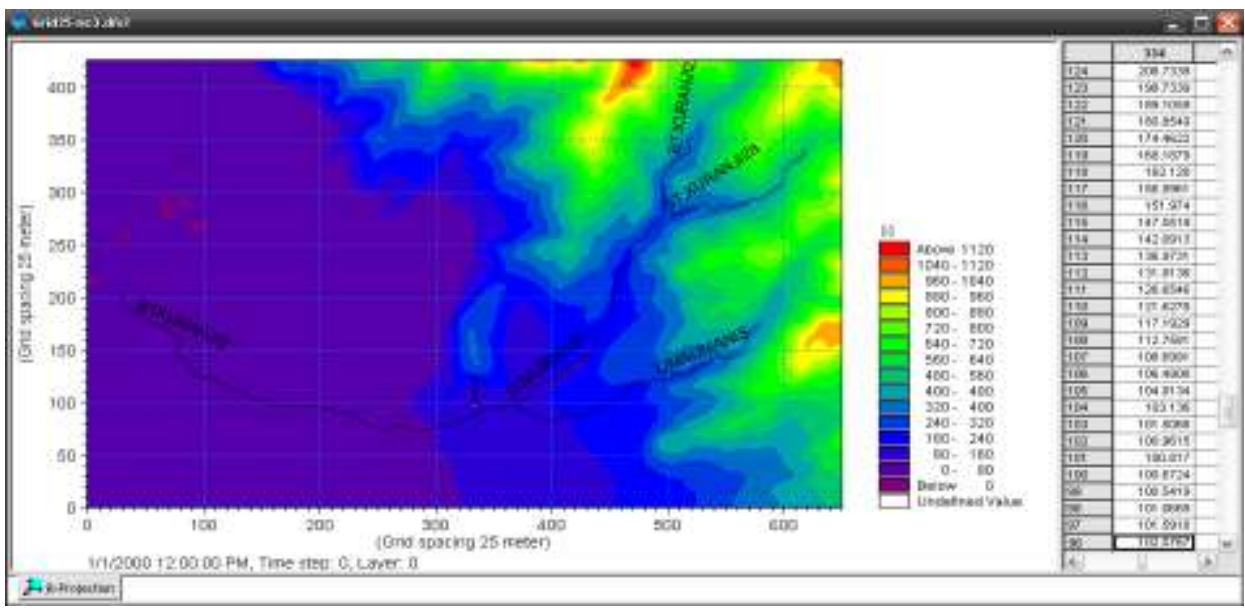

Sumber : Laporan BNPB Sumbar 2014

Gambar 4. Peta Genangan Banjir DAS Sungai BT.Kuranji

\section{Simulasi banjir}

Analisis frekuensi dilakukan dengan menggunakan software berdasarkan input data berupa seri hujan harian maksimum tahunan (maximum annual series) selama rentang waktu 37 tahun yaitu dari tahun 1975-2012. Dengan analisis frekuensi akan diperkirakan besarnya curah hujan rancangan untuk berbagai kala ulang sebagai input dalam perhitungan debit untuk syarat batas hulu dan lateral inflow yaitu hujan rancangan DAS Sungai BT Kuranji dan Anak -anak Sungainya,. Hujan rancangan selengkapnya ditunjukkan pada Tabel 1.

Tabel 1 Rekapitulasi Debit Banjir Maksimum Dengan Metode Nakayashu Untuk Setiap STA Hujan

\begin{tabular}{|c|c|c|c|c|c|}
\hline \multirow{2}{*}{ NO } & \multirow{2}{*}{$\begin{array}{c}\text { Kala Ulang } \\
\text { ( Tahun ) }\end{array}$} & \multicolumn{4}{|c|}{ Rekapitulasi Debit Banjir Maksimum Setiap STA Hujan ( Q } \\
& & $\begin{array}{l}\text { Limau } \\
\text { Manis }\end{array}$ & Pdg Jernih & Pdg Keruh & Gng Nago \\
\hline 1 & 1.0 & 294.5 & 201.3 & 441.9 & 294.5 \\
\hline 2 & 2.0 & 388.5 & 265.5 & 583.0 & 388.5 \\
\hline 3 & 5.0 & 466.0 & 318.5 & 699.3 & 466.0 \\
\hline 4 & 10.0 & 512.5 & 350.3 & 769.1 & 512.5 \\
\hline 5 & 20.0 & 554.4 & 378.9 & 831.9 & 554.4 \\
\hline 6 & 50.0 & 605.6 & 413.9 & 908.8 & 605.6 \\
\hline 7 & 100.0 & 719.3 & 491.6 & 1079.4 & 719.3 \\
\hline 8 & 1000.0 & 1412.2 & 965.2 & 2119.1 & 1412.2 \\
\hline
\end{tabular}

Sumber : Dokumen BWS V Sumnar

Tabel 2 Rekapitulasi Debit Banjir CheckDam Kuranji Metode Nakayashu

\begin{tabular}{|l|c|c|l|c|c|}
\hline $\begin{array}{l}\mathrm{N} \\
\mathrm{o}\end{array}$ & $\begin{array}{c}\text { Kala Ulang } \\
(\text { Tahun })\end{array}$ & $\begin{array}{c}\text { Debir banjir } \\
\mathrm{Q}(\mathrm{M} 3 / \mathrm{dt})\end{array}$ & $\begin{array}{l}\mathrm{N} \\
\mathrm{o}\end{array}$ & $\begin{array}{c}\text { Kala Ulang } \\
(\text { Tahun })\end{array}$ & $\begin{array}{c}\text { Debit Banjir } \\
(\mathrm{Q} \text { m3/dt })\end{array}$ \\
\hline 1 & 1.0 & 441.9 & 5 & 20.0 & 831.9 \\
\hline 2 & 2.0 & 583.0 & 6 & 50.0 & 908.8 \\
\hline
\end{tabular}


Vol. 2 No.2 Juni 2019

http://jurnal.umsb.ac.id/index.php/RANGTEKNIKJOURNAL

\begin{tabular}{|l|c|c|l|l|l|}
\hline 3 & 5.0 & 699.3 & 7 & 100.0 & 1079.4 \\
\hline 4 & 10.0 & 769.1 & 8 & 1000.0 & 2119.1 \\
\hline
\end{tabular}

Sumeber : Dokumen BWS V Sumbar

\section{Manajemen Bencana}

Menurut UU Nomor 24 Tahun 2007, manajemen bencana dari data banjir diatas adalah suatu proses dinamis, berlanjut dan terpadu untuk meningkatkan kualitas langkahlangkah yang berhubungan dengan observasi dan analisis bencana serta pencegahan, mitigasi, kesiapsiagaan, peringatan dini, penanganan darurat, rehabilitasi dan rekonstruksi bencana, sebagaimana digambarkan pada gambar berikut :

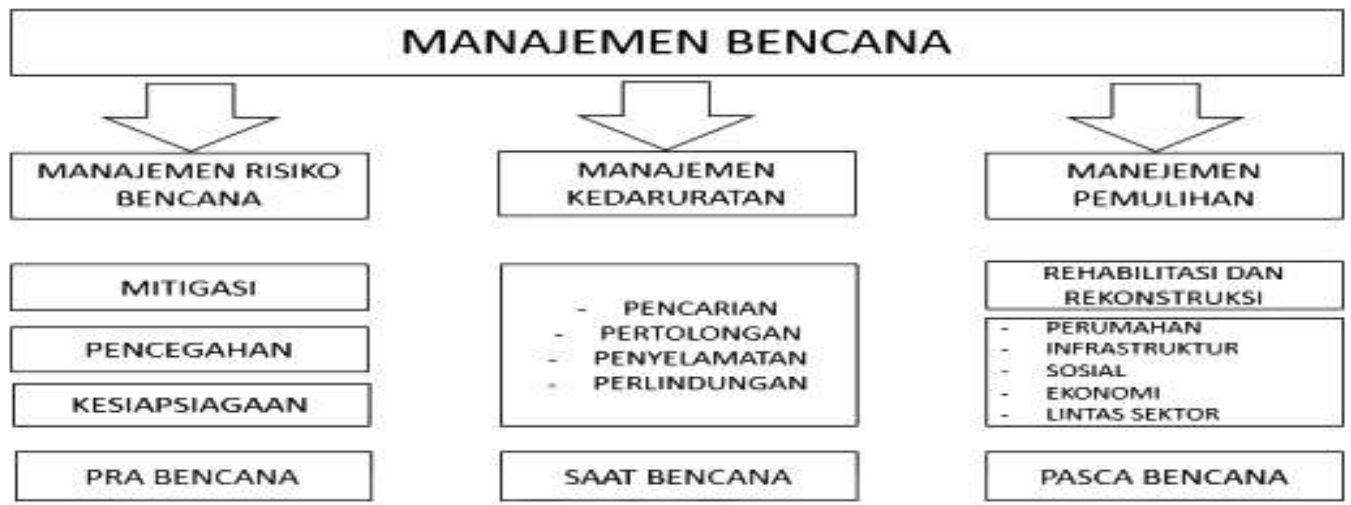

Gambar 5. Diagram Manajemen Bencana

\section{PENUTUP}

Berdasarkan hasil analisis dan pembahasan dari penelitian ini yang telah diuraikan sebelumnya, maka dapat diambil kesimpulan yaitu:

1. Pada saat banjir datang terjadi peluapan pada tanggul sungaidengan tinggi peluapan dari $0.20 \mathrm{~m}$ sampai $3.66 \mathrm{~m}$ pada daerah sub Das kuaranji 2 pada daerah dataran .

2. Dari hasil analisis dan simulasi terdapat daerah potensi terendam lebih kurang sebesar $28.000 \mathrm{~m} 2$ didaerah sekitar sungai

3. Tampungan efektif kolam retensi yang dibutuhkan kondisi pada saat elevasi muka air naik dibutuhkan volume tampungan di kolam retensi sebesar 100,800 M 3 untuk luas genangan $28 \mathrm{Ha}$.

4. Kolam retensi mampu menampung dan menahan banjir selama 3-4 jam berdasarkan hasil penelusuran (routing) pada beban banjir kala ulang 2 dan 5 tahun, dan menurunkan muka air banjir secara merata di hilir dan di sekitar lokasi retarding basin rata-rata 0,20 meter.

5. Dalam hal penelusuran banjir dikota padang untuk Das Sungai Batang Kuranji ini dibutuhkan areal lebih kurang 28 sampai 50 Ha.

\section{REFERENSI}

Anonim, 2009. Studi Mitigasi Penangan Bahaya BanjirPekerjaan Pembangunan Pengendalian Banjir Dan Sedimen Sungai Batang kuranji Balai Wilayah Sungai V Sumatera Barat,Padang 2014

Deviana,Aninda,dkk.2014.Kajian Pemodelan Spasial Banjir Untuk Mendukung Kebijakan Sempadan Sungai Dan Tata Ruang Wilayah,Jurnal.Institut Teknologi Bandung,2014

Aryadi, N.M, 2011. Kajian Alternatif Pengendalian Banjir di Tukad 
Mati,Universitas Gadjah Mada,

Yogyakarta.

Pande Suryadinata I.Gede,dkk,2012 Rencana Pengendalian Banjir Tukat Mati Dengan Retarding Basin,Prosiding Pertemuan Imiah Tahunan HATHI,Bandung.

Kodoatie, R. dan Sugiyanto, 2002. Banjir, Beberapa Penyebab dan Metode Pengendaliannya dalam Perspektif Lingkungan. Pustaka Pelajar, Yogyakarta.

Kodoatie, R. , 2013.Rekayasa Dan Manajemen Banjir Kota,Penerbit Andi. Yogyakarta.

Linsley R.K dan Franszini J.B. 1986. Teknik Sumber daya Air. Terjemahan. Penerbit Erlangga, Jakarta.

Sebastian, L., 2008. Pen dekatan Pencegahan dan Penanggulangan Banjir. Dinamika Teknik Sipil. Fakultas Teknik Universitas Palembang. Vol.8 No.02 Juli 2008 hal. 162-169. Palembang.

Wahyudi, J., 2009. Kajian Penanganan Banjir Pada DAS Sekanak Kota Palembang). Universitas Gadjah Mada, Yogyakarta.

DHI Software (2014). MIKE 11 User Manual and Tutorial.DHI Software (2014) .MIKE View User Manual.

Gilles D. and M. Moore (2010) 'Review of Hydraulic Flood Modeling Software used in lgium, The Netherlands, and the United Kingdom', Int. Perspectives in Water Resource Management, IIHR, Hydroscience \& Engineering University of Iowa 